\title{
A NEW EDIACARAN FOSSIL WITH A NOVEL SEDIMENT DISPLACIVE LIFE HABIT
}

\author{
MARY L. DROSER, ${ }^{1}$ JAMES G. GEHLING,${ }^{2,4}$ MARY E. DZAUGIS, ${ }^{3}$ MARTIN J. KENNEDY, ${ }^{4}$ DENNIS RICE, ${ }^{2}$ \\ AND MICHAEL F. ALLEN ${ }^{5}$ \\ ${ }^{1}$ Department of Earth Sciences, University of California, Riverside, CA 92521, USA, <mary.droser@ucr.edu>; ${ }^{2}$ South Australia Museum, North \\ Terrace, Adelaide, South Australia 5000; ${ }^{3}$ Graduate School of Oceanography, University of Rhode Island, Narragansett Bay Campus, \\ Narragansett, RI 02882, USA; ${ }^{4}$ School of Earth and Environmental Science, University of Adelaide, Adelaide, South Australia 5005; and \\ ${ }^{5}$ Center for Conservation Biology, University of California, Riverside, CA 92521, USA
}

\begin{abstract}
Nilpenia rossi new genus new species, described here from the Ediacara Member (Rawnsley Quartzite, South Australia), provides evidence of a Precambrian macroscopic sessile sediment-dweller. Nilpenia, ranging up to $30 \mathrm{~cm}$ in diameter, consists of two zones, a complex central area surrounded by radiating, dichotomously branching structures that decrease in diameter from the center to the outer edges. Other elements of the Ediacara Biota are interpreted to have been mat-encrusters but Nilpenia uniquely grew within the upper millimeters of the actual sediment displacing sediment with growth. This sediment surface was rippled and cohesive and may well have included an endobenthic mat. The branching network on the upper surface of the organisms would have been in contact with the water. The phylogenetic relationships of the Ediacara biota are not well constrained and Nilpenia is no exception. However, the morphology and ecology of Nilpenia represent a novel growth strategy present in the Ediacaran and not common today.
\end{abstract}

\section{INTRODUCTION}

$\mathrm{E}$ DIACARAN STRATA contain the earliest diverse macroscopic fossils, the so-called Ediacara biota, known from numerous localities globally (Narbonne, 2005; Xiao and Laflamme, 2009) providing a critically important, if highly contested, picture of Neoproterozoic biology and ecology. Traditionally, the majority of these fossils were placed in modern animal phyla. Radially symmetrical and sea-pen like forms have generally been assigned to the Cnidaria, and segmented more or less bilaterally symmetrical forms identified as having affinities to annelids and arthropods (e.g., Glaessner, 1984; Gehling, 1991). In most cases, problems in finding unequivocal morphological characters linking them to modern phyla, as well as their unusual style of preservation, prompted suggestions of alternative taxonomic affinities ranging from an extinct kingdom of "Vendobionts" (Seilacher, 1992), to mesozoans (McMenamin, 1998), prokaryotic colonies (Steiner and Reitner, 2001), protists (Zhuravlev, 1993), lichens (Retallack, 1994) and fungi (Peterson et al., 2003). While the phylogenetic affinities of these taxa remain the subject of considerable debate, the in situ nature of these fossils allows another approach; an ecological perspective can be gained from examining the possible modes of life, fossil associations, and insights from taphonomy.

The Flinders Ranges of South Australia expose one of the best successions of Neoproterozoic rocks in the world and includes the type section of the Ediacaran Period. Both the structure and associations of Ediacara fossils of the Flinders Ranges area provide information of the complex ecological makeup of Earth's first multicellular habitat (Droser et al., 2006). In particular, extensive bedding plane exposures allow for analysis of significant numbers of specimens in situ including abundant taphonomic variants.

The fossiliferous Ediacara Member of the Rawnsley Quartzite is located $50-500 \mathrm{~m}$ below a basal Cambrian disconformity and consists of medium-grained sandstone beds deposited in shallow-marine environments with widespread microbial mats (Gehling and Droser, 2012). The Ediacara Member fills southeastern trending paleovalleys cut into the Chace Quartzite Member of the Rawnsley Quartzite, and in turn is disconformably overlain by the early Cambrian Uratanna Formation, bearing the first complex assemblage of trace fossils and rare body fossils (Jensen et al., 1998; Gehling, 2000; Gehling et al., 2012).

We examined beds within the Ediacara Member on the National Heritage Ediacara Fossil Site at Nilpena, west of the Flinders Ranges in South Australia (Fig. 1). Over 350 specimens were recorded on several horizons within a single distinctive facies association of the Ediacara Member, but are unknown elsewhere in the succession. They occur exclusively on bed tops, since the expected counterparts in the overlying silty laminae are not preserved. Rare trails referable to Helminthoidichnites are the only other fossils occurring on these bed tops.

NATURE OF MATERIAL

Nilpenia rossi $\mathrm{n}$. gen. n. sp. occurs most commonly on thin- to medium-bedded ripple-laminated sandstones, centimeters in thickness, that preserve asymmetrical linguoid ripples on bed tops (Fig. 2). These beds are part of the Delta-Front Sands facies consisting overall of poorly sorted red, laminated silty sandstone in coarsening, thickening upward bed sets interpreted as having been deposited below fair-weather wave-base (Gehling and Droser, 2013). The grain size and evidence of intermittent tractional deposition suggests a low energy marine environment. On a given bedding plane, Nilpenia occurs abundantly. There is no evidence that the organisms or their fossils were transported. The preservation of the rippled surfaces as well as the body fossils indicate that these surfaces were not reworked and must have been stable long enough for the growth of the organism. Bed bases commonly preserve clusters of small Aspidella discs, rare casts of tubes and tool marks made by transported semilithified sandstone clasts. Elsewhere at Nilpena, additional Nilpenia specimens occur on tops of beds in the same sedimentary facies where bed bases preserve typical members of the Ediacara biota such as discoidal casts of Aspidella, Eoporpita, Parvancorina, Dickinsonia, Kimberella, Albumares 


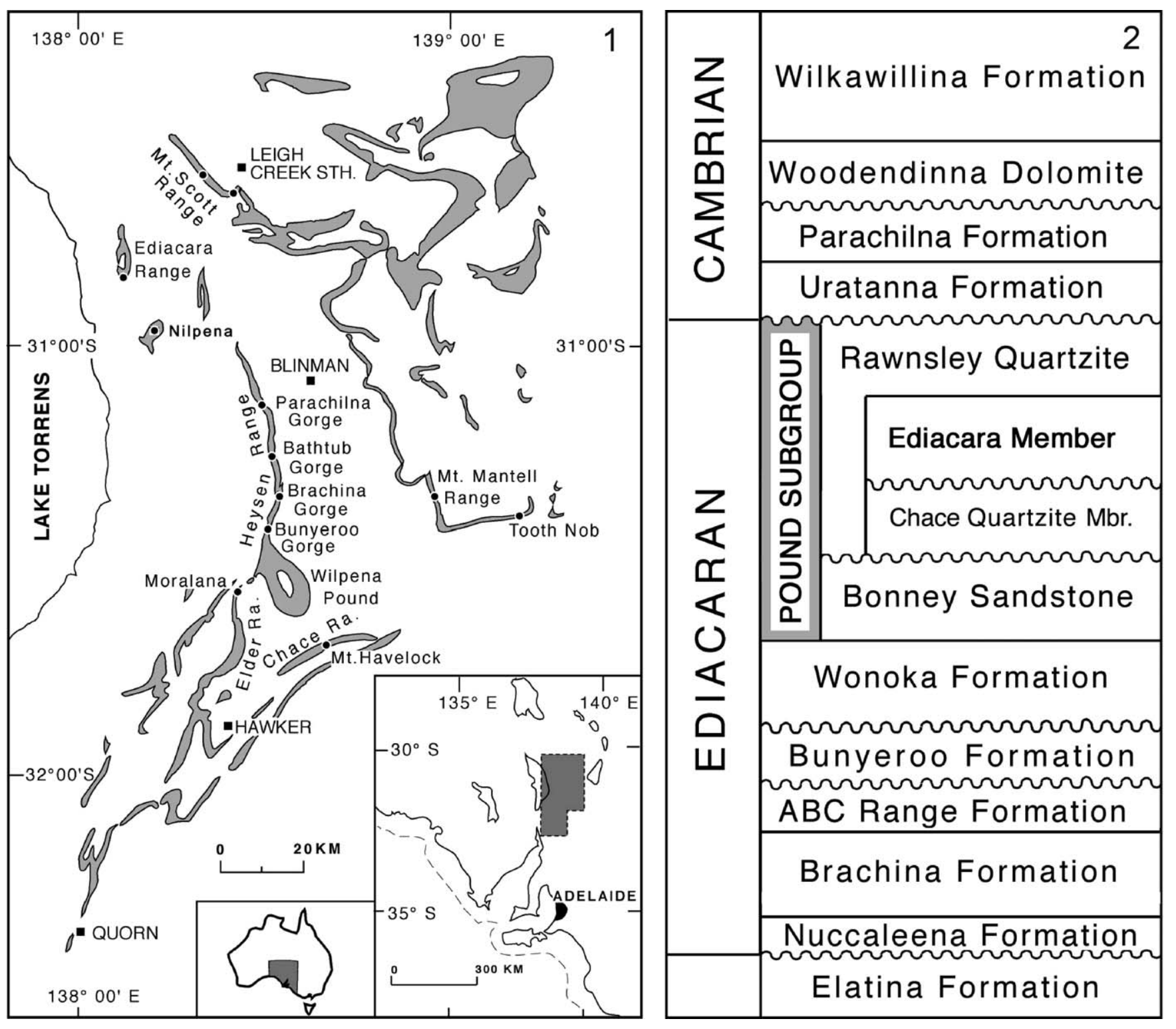

FIGURE 1 - Locality map and stratigraphic column. Nilpenia rossi n. gen. n. sp. locality is indicated by star. Fossils are from the Ediacara Member of the Rawnsley Quartzite.

and also three-dimensional rangeomorphs including Rangea and Charnia.

\section{SYSTEMATIC PALEONTOLOGY}

Genus NilPenia new genus

Type species.-Nilpenia rossi new species.

Diagnosis.-As for species.

Etymology.-Generic name in honor of the National Heritage Listed Ediacara Fossil Site at Nilpena, the type locality.

Occurrence.-Ediacara Member, Rawnsley Quartzite, the National Heritage Listed Ediacara Fossil Site at Nilpena, Flinders Ranges, South Australia.

\section{NiLPENIA ROSSI new species}

Figure 2

Diagnosis. - Outline circular to fan-shaped ranging from $8 \mathrm{~mm}$ to $280 \mathrm{~mm}$ in widest diameter. Corrugated sheet consisting of radiating and bifurcating grooves terminating in a distinct raised rim in most specimens greater than $40 \mathrm{~mm}$ in diameter.
Indistinctly defined diamond-shaped, densely packed ridges less than $5 \mathrm{~mm}$ across forming central portion of all specimens greater than about $30 \mathrm{~mm}$ in diameter and in some smaller specimens. Central portion can comprise up to half the specimen. Grooves are 0.2 to $2 \mathrm{~mm}$ in width and radiate from the center. Grooves commonly bifurcate as to completely cover substrate and in larger specimens, decrease in width away from central portion and rarely around perimeter of organism.

Description.-The fan- and circular-shaped form of the larger specimens of Nilpenia rossi (Fig. 2.1) can be divided into two components: 1) a central portion typically poorly preserved in positive epirelief as a series of diamond shaped ridges or more typically a poorly defined irregular surface (Fig. 2.1, 2.2) and, 2) with grooves that radiate from the central portion as part of a corrugated sheet (Fig. 2). The grooves are preserved in negative relief on the bed tops indicating that the organism grew into the upper-most layer of the sediment, displacing sediment with growth. The grooves are millimetric in width, rarely submillimetric, and the preservation of such fine features is limited only by grain size. These radial networks have several characteristics. 
They branch dichotomously and, on larger specimens, grooves are densely packed throughout the fossil and may systematically decrease in width distally from the center. Grooves do not cross each other in the peripheral zone, but appear to interfere in the central zone of the larger, circular specimens (Fig. 2.1-2.3). Furthermore, on most specimens and all larger specimens, branching results in complete coverage of the substrate within the fan or circle defined by the radiating grooves. The angle of branching measured from 209 angles on 77 specimens ranged between $3-84^{\circ}$ with an average of $32^{\circ}$. Grooves can also decrease in width around perimeter of organism but do so systematically (Fig. 2.6). On smaller specimens ( $<4 \mathrm{~cm}$ in radius), the center portion may not be developed and grooves may radiate from a single point in a "fan-like" manner and are less densely packed (Fig. 2.9, 2.10). However, proximal groove width is similar on all specimens; smaller specimens do not have smaller groove width. The outer portion of specimens may not be defined in smaller specimens and grooves may extend out in varying lengths from the center but larger specimens end with a distinct outer rim (Fig. 2.10).

Etymology.- Species name in honor of Ross Fargher for his commitment to the conservation of these fossils.

Holotype.-SAM P47049 (South Australia Museum).

Occurrence.-Ediacara Member, Rawnsley Quartzite, the National Heritage Listed Ediacara Fossil Site at Nilpena, Flinders Ranges, South Australia.

Remarks.-Nilpenia n. gen. was preserved as a product of displacement of the surface sediment on well-preserved linguoid ripples with over-steepened lee sides that suggest microbial stabilization of the sand-surface. These dichotomously branching grooves are interpreted as the collapsed, shallowly buried radial network of branching tubes that formed part of a radially corrugated sheet (Fig. 3), where the tubes collapsed after burial. The resulting fossils consist of a network of branching grooves outlined by faint ridges in the sand surface (Fig. 2). In mature specimens (Fig. 2.1-2.3), the central zone may have represented a more substantive part of the body that maintained its integrity after burial as is the case fossils such as Dickinsonia. It is also possible that the central part represents amalgamated layers of tubes

There are several distinct aspects to the growth series of Nilpenia. The overwhelming majority of specimens are under 10 $\mathrm{cm}$ in diameter; specimens can range up to nearly $30 \mathrm{~cm}$ in diameter (Fig. 4). Furthermore, specimens with a radius of over $30 \mathrm{~mm}$ all have a central portion, while smaller specimens typically have a node of origin rather than a developed central portion (Figs. 2.2, 4). Larger specimens may also exhibit a subtle zonation from the center to the outer rim. The small specimens (under $2.5 \mathrm{~cm}$ ) typically have a fan shape with an angle of less than $45^{\circ}$ radiating from a small point of initiation. Some of the larger specimens are also fan shaped and amongst those that are circular, there may be varying but systematic changes in groove width suggesting different phases of growth. The similar range of proximal groove widths on all specimens; that is smaller specimens do not have systematically smaller groove widths in comparison to larger specimens is consistent with growth at the distal edges.

\section{TAPHONOMY}

Preservation is fundamentally different from other elements of the Flinders Ranges Ediacara Biota in several significant ways. Fossils of the Ediacara Biota in the Flinders Ranges are typically best preserved on the base of beds as external molds of the organisms. Benthic organisms living on the Ediacaran seafloor were smothered by sand. Microbially mediated early cementation of this overlying sand lead to the molding of the upper surface of the organisms before they decayed (Gehling,
1999). An important function of the microbial films that are hypothesized to have coated these fossiliferous surfaces is that they firstly acted as a separator between the original sandy substrate and the burial sand laminae. After decay and collapse of tubular elements, sand from below filled the overlying mold. Thus, most fossils preserved on bed tops represent the cast of molds of organisms and are typically not well preserved. In contrast, unlike all of the other elements of the Ediacara Biota, Nilpenia $\mathrm{n}$. gen. is best preserved on bed tops. The counterparts, as external molds, which would be found on the base of overlying beds are not preserved because the sand laminae are thin and discontinuous. The other significant aspect of Nilpenia preservation is that part of each individual is preserved in positive relief and part in negative relief. The combination of negative and positive relief suggests that the organism had varying rigidity. Preservation of positive relief indicates that after the sand was deposited on top of the organism the center section maintained its integrity long enough for the sand to permanently cast the organism through mineralization. The negative portion suggests that that part of the proposed tubular peripheral network of the organism collapsed after burial.

\section{DISCUSSION}

The unusual morphology and taphonomy of Nilpenia rossi n. gen. n. sp. constrains the possible phylogenetic associations. The well-preserved linguoid ripples and preservation of grooves on a bed top indicate that the organisms inhabited a firm and cohesive substrate such that the grains locally stuck together and responded as a coherent mass to current flow. Given the evidence of microbials mats in the Ediacaran, it is likely that there was some endobenthic mats present. The disruption of the upper layer of sediment implies that these organisms actively grew within the upper millimeters of the sediment. In contrast, other elements of the Ediacara Biota are interpreted to have been mat encrusters but they did not affect the underlying sedimentary surface. Only the trace fossil Helminthoidichnites, made by an organism clearly burrowing within the top of the sediment, and fanned sets of radular traces, attributed to the putative bilaterian, Kimberella, show a similar disruption of the sedimentary surface. Thin sections reveal that Nilpenia was not a borer but rather displaced sediment with growth.

Given the similar preservation, it is not surprising that the morphology of some specimens of Nilpenia bear superficial resemblance to a trace fossil, particularly in that trace fossils are also preserved in negative relief on the tops of Ediacaran beds surfaces. Specimens of Nilpenia have been previously interpreted as both the trace fossils Chondrites (Jenkins, 1995) and Oldhamia (Gingras et al., 2011). While Nilpenia does dichotomously branch, it clearly lacks the regular bifurcating pattern of Chondrites and its active infill. Oldhamia is a characteristic trace fossil of Cambrian rocks most recently interpreted as the trace fossil of an undermat miner typically in deep water (Seilacher et al., 2005). Individual specimens of Nilpenia can closely resemble Oldhamia, but when all of the specimens are taken into account, a trace fossil origin is not parsimonious. The diamond shaped positive relief structure that characterizes the central portion of Nilpenia (Fig. 2.1, 2.2) cannot be reconciled with a trace fossil origin. Most significantly, the systematic decrease in diameter within a branch and around the diameter of the whole organism similarly precludes a trace fossil origin. The proximal to distal zonation that occurs in larger specimens is also inconsistent with a trace fossil origin. Specimens of Ediacaran-aged Oldhamia recta from North America, though quite dissimilar from Nilpenia rossi have been reinterpreted as body fossils of a rod-like organism (Tacker et al., 2010). 




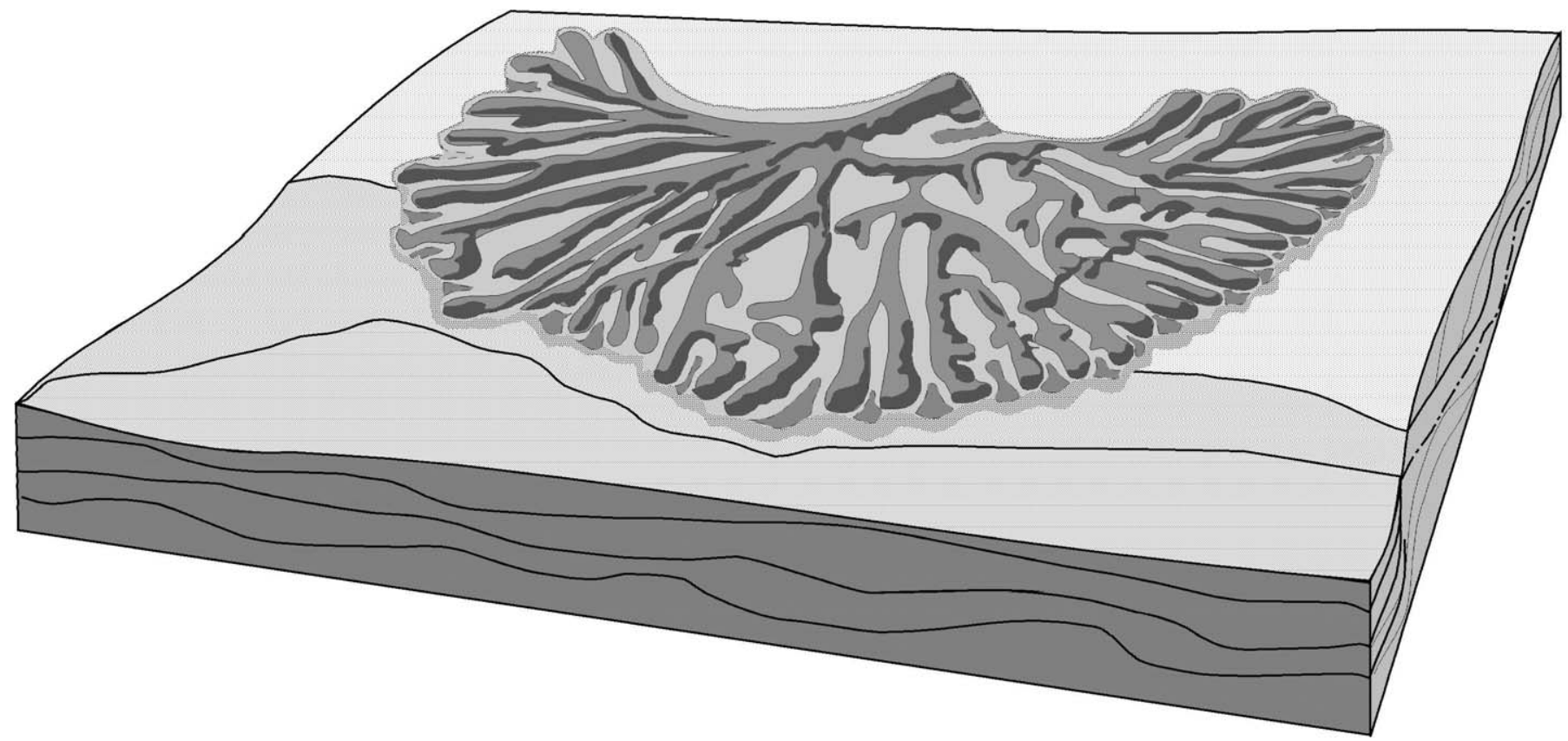

FIGURE 3-Reconstruction of an immature fan-shaped specimen of Nilpenia, before the entire circumference was populated by branching ridges and before secondary growths had developed over the central zone.

Comparison with the record of delicate dendritic networks on ripple crests, referred to as "Aristophycus", has been rejected since, unlike Nilpenia, "Aristophycus" is dewatering structure converging on ripple tops (Seilacher, 2007). Nilpenia has no preferred position on ripples and in many cases the convergence of the branching grooves is lower than the remainder of the fossil on rippled surfaces.

No known extant animals have this form; encrusting bryozoans, sponges and cnidarians are most similar but are not differentiated from center to margin with well defined linear structures radiating from the center but rather would have modular units forming sheet- like colonies. Furthermore, sponges, including encrusting sponges, have a well-defined oscula. This is not consistent with the morphology of Nilpenia. While larger Nilpenia have a differentiated central section, it is preserved in positive relief on bed tops. This implies that the central portion would have been solid and resistant, the opposite of the prediction made by an oscular opening of a sponge. Most significantly, while not fully infaunal, Nilpenia lived within the sediment, perhaps within a sandy endobenthic mat. Only the upper surface of the organism would have been exposed to water. Infaunal sponges are known but rare and the main body is within the sediment with siphons extending to the surface (Werding and Sanchez, 1991).

Fossils of the Ediacara biota have been interpreted as Xenophyphores, the extant large single-celled foraminifera. Antcliff et al. (2011) recently evaluated this hypothesis for the Ediacarn taxa Palaeopascichnus as well as the Ediacara biota in general. While they acknowledge that there are good arguments for the presence of primitive foraminifera and related taxa, in the Ediacaran, there is no convincing evidence of these among the Ediacara biota. Several aspects of their argument are relevant here; most importantly, Xenophyophores are unlikely to be represented in the Ediacaran Period as they are a group of recently evolved Foraminifera. Nilpenia is larger than known giant foraminifera and shows no evidence of chambers. Thin sections reveal no evidence of material that might represent agglutinated particles in the grooves or associated with the grooves.

Nilpenia bears some resemblance to a root or holdfast but the morphology of only a few of the specimens would be consistent with this type of origin. The smaller forms generally do not have a differentiated center and are typically just a fan of dichotomously branching structures preserved as grooves (Fig. 2.6, 2.9). While the larger forms typically do have a differentiated center - it is most commonly irregularly shaped which is not consistent with any known stalk, the ratio of the center to the diameter is variable and is commonly a continuation of the groove structures themselves - commonly merging (Fig. 2.3). These characteristics rule out a holdfast origin.

Significantly, Nilpenia is dissimilar to other known Ediacaran fossils such as Dickinsonia, Funisia, Spriggina and frondose forms in that it grew within the sediment and is almost always preserved in association with linguoid current ripples. This upper sediment surface may likely have had an endobenthic mat incorporated into the sediment, but Nilpenia was not a mat encruster in the sense of other Ediacara forms that are interpreted to have been mat encrusters (Seilacher et al., 2003). Nilpenia is also dissimilar from other Ediacara forms

FIGURE 2-Nilpenia rossi n. gen. n. sp. preserved as external casts on bed tops. 1, holotype circular in shape with dichotomous branching grooves maximizing surface area and a well-developed middle preserved in positive epirelief, SAM P47049; 2, well-defined edge of corrugated sheet (arrow), densely packed grooves and ridges, SAMP47053; 3, maximizing surface area, SAMP47055; 4, 5, fan-shaped specimens with dichotomous branching, SAM P47050, SAMP47056; 6, fan shaped, grooves decrease in diameter (arrow), SAMP47052; 7, grooves decreasing in diameter radially, SAMP47055; 8, form over ripple, distinct outer rim of sheet (arrow), SAM47057; 9, 10, small fan-shaped specimens with a point of origin without middle, SAMP47058, SAMP47054. Scale bars=1 cm. 


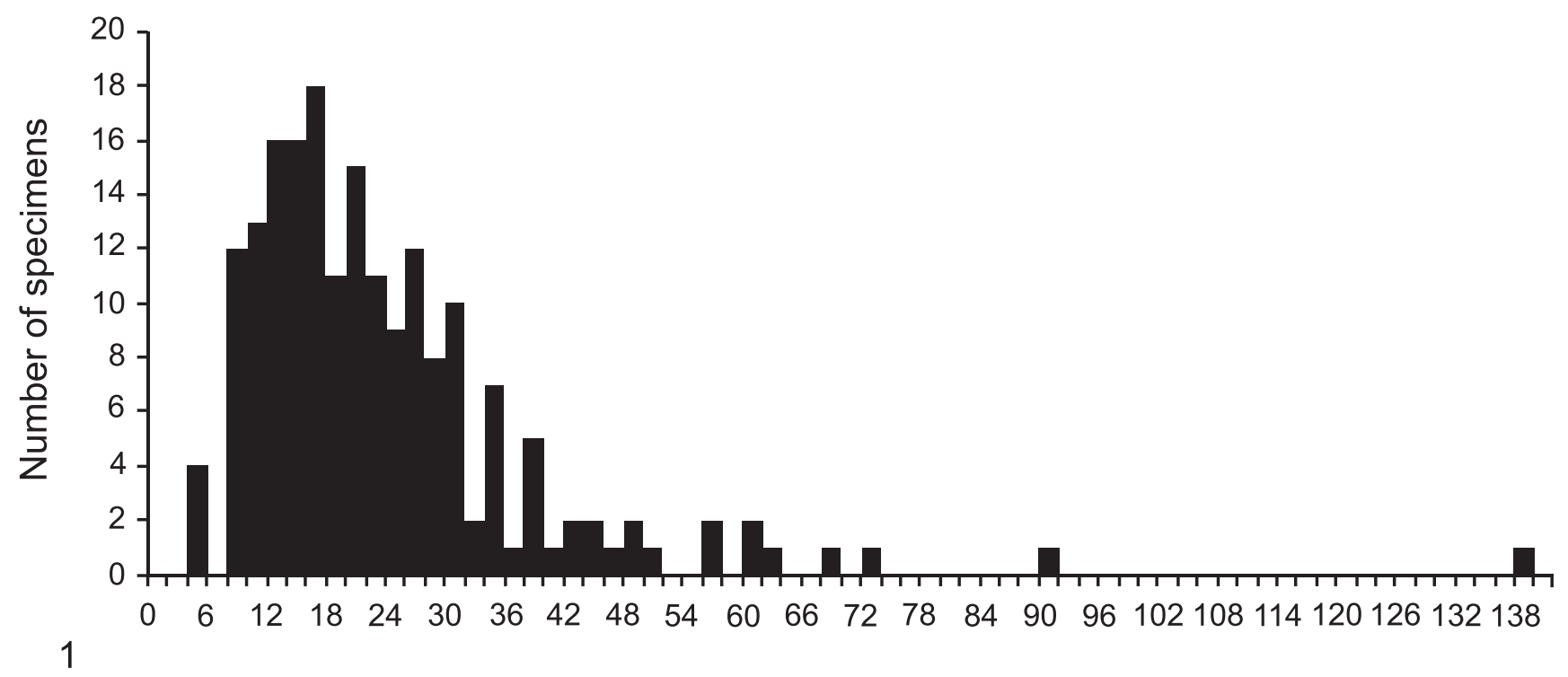

\section{Radius (mm)}

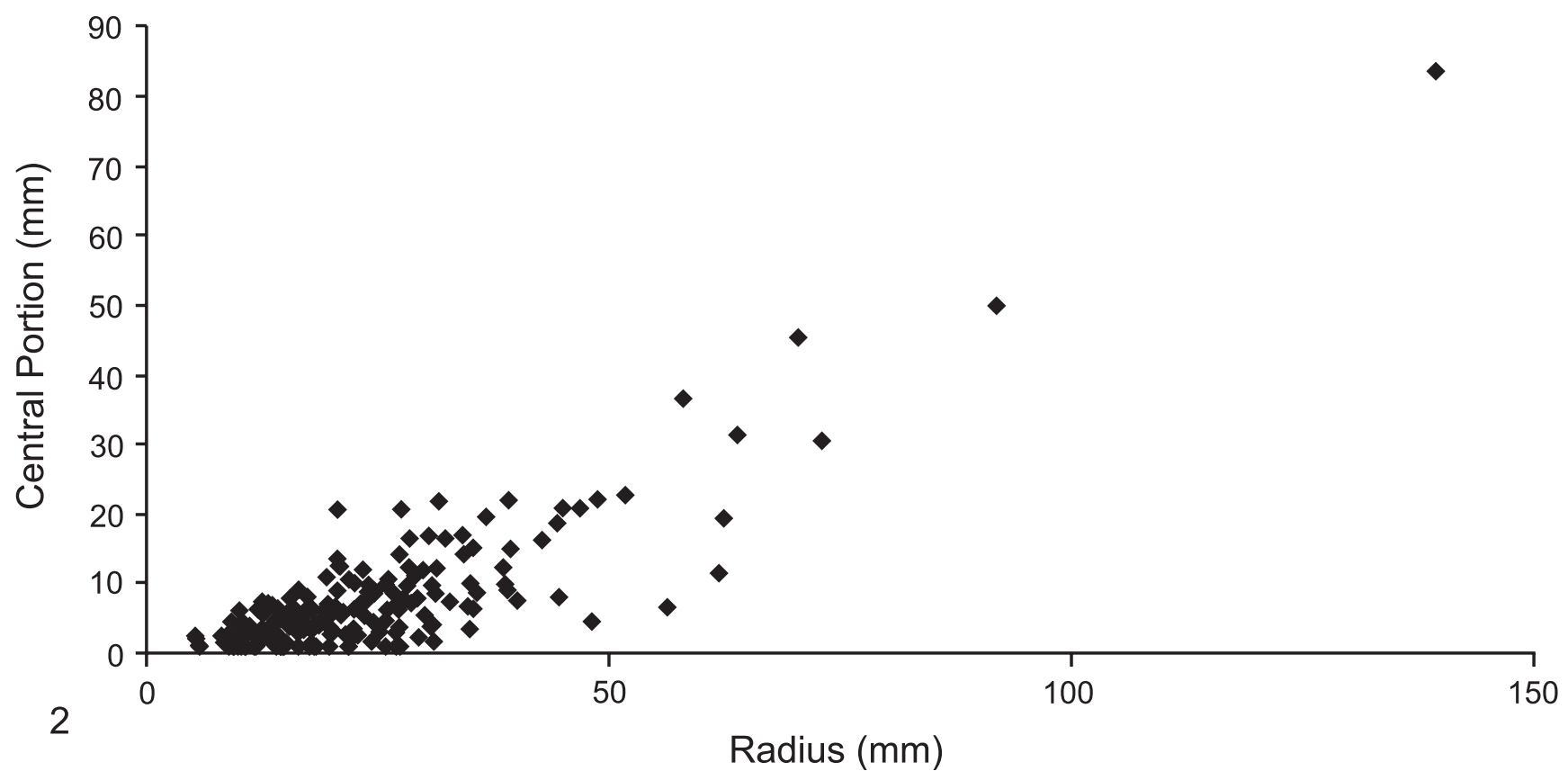

FIGURE 4-1, size frequency diagram of Nilpenia rossi demonstrating right-skewed population structure; 2, radius of central portion of Nilpenia plotted against full radius. While many specimens less than $40 \mathrm{~mm}$ in radius have a central portion, none above $40 \mathrm{~mm}$ are lacking the central portion. Measurements were made of the radius so that incomplete specimens could be included.

in that it does not have defined edges with a consistent outer morphology and a regular geometric form.

In gross morphology, Nilpenia is similar to an encrusting alga. Algae can branch dichotomously but in the case of Nilpenia the zoning along with coordinated growth among different branches is not consistent with an alga and algae do not typically live within the sediment. Nilpenia does exhibit a growth strategy similar to fungi and lichen. The center portion, typically poorly preserved, is present only in larger and presumably older specimens (Fig. 4.2). This is consistent with die-back of the older portions of a colony. The dichotomously expanding grooves narrow from the center to margin and in some specimens the grain size limits our ability to resolve the width. Secondary colonies (Fig. 2.4, 2.6) can be observed and are also consistent with fungi. Significantly, Nilpenia lived within an unambiguous marine substrate and was orders of magnitude larger than one would expect for a lichen or fungus. Microstructure is not preserved in Nilpenia or other fossils of the Ediacara Biota at Nilpena, limiting our ability to definitively identify Nilpenia as an alga, fungus or lichen or alternatively, a protist or an animal.

However, at the very least, its dichotomous branching, radiating growth form allowed for maximal exploitation of organic resources from an initial growth point (such as a spore 
or fragment). Exploitation of the organic resources of organic material within a mat has been interpreted as a mode of life for Dickinsonia, but in that case, Dickinsonia was able to move to potentially acquire more resources (Gehling et al., 2005) whereas Nilpenia possibly grew further into the sediment to obtain more resources. Interpretations on gross morphology alone coupled with the anactualistic nature of the Ediacaran seafloor do not allow for a clear interpretation of phylogenetic relationships in this case. Nilpenia should be regarded as an organism of unknown affinities with a growth pattern convergent on that of extant fungi, lichens and encrusting algae with an ecology unlike others of the Ediacara biota and perhaps unlike common ecologies today.

\section{ACKNOWLEDGMENTS}

This research was supported by a National Science Foundation grant (EAR-0074021) and a NASA grant (NNG04GJ42G NASA Exobiology Program) to MLD and an Australian Research Council Grant (DP0453393) to JGG. We are indebted to Jane and Ross Fargher for access to their property and permission to excavate fossiliferous beds. We are also grateful to the Ediacaran Foundation for support for this project. S. Jensen aided with fieldwork and N. Hughes, G. Mangano, P. Taylor and R. Wood provided helpful comments.

\section{REFERENCES}

Antcliff, J. B., A. J. Gooday, And M. D. Brasier. 2011. Testing the protozoan hypothesis for Ediacaran fossils: a developmental analysis of Palaeopascichnus. Palaeontology, 54:1, 157-1,175.

Droser, M. L., J. G. Gehling, and S. R. Jensen. 2006. Assemblage palaeoecology of the Ediacara biota: the unabridged edition? Palaeogeography, Palaeoclimatology, Palaeoecology, 232:131-147.

GeHLING, J. G. 1991. The case for Ediacaran fossil roots to the metazoan tree. Geological Society of India Memoir, 20:181-224.

Gehling, J. G. 1999. Microbial mats in terminal Proterozoic siliciclastics: Ediacaran death masks. Palaios, 14:40-57.

GeHLING, J. G. 2000. Environmental interpretation and a sequence stratigraphic framework for the terminal Proterozoic Ediacara Member within the Rawnsley Quartzite, south Australia. Precambrian Research, 100:65-95.

Gehling, J. G., J. B. Jago, J. R. Paterson, G. A. Brock, And M. Droser. 2012. Ediacaran-Cambrian of South Australia. Field Trip, 11-18 Aug., 34th International Geological Congress, 5-10 Aug, 2012. Brisbane, p. 36.

Gehling, J. G., M. L. Droser, S. Jensen, and B. N. Runnegar. 2005. Ediacaran organisms: relating form to function, p. 43-67. In D. E. G. Briggs (ed.), Evolving Form and Function: Fossils and Development, Proceedings of a Symposium Honoring Adolf Seilacher for his contributions to palaeontology in celebration of his 80th Birthday. Peabody Museum of Natural History, Yale University, New Haven, Connecticut, U.S.A.

Gehling, J. G. And M. L. Droser. 2012. Ediacaran stratigraphy and the biota of the Adelaide Geosyncline, South Australia. Episodes 35:236-246.
Gehling, J. G. And M. L. Droser. 2013. How well do fossil assemblages of the Ediacara Biota time? Geology, 41:447-450.

Gingras, M., J. W. Hagadorn, A. Seilacher, S. V. Lalonde, E. Pecoits, D. Petrash, and K. O. Konhauser. 2011. Possible evolution of mobile animals in association with microbial mats. Nature Geoscience, 4:372-375.

Glaessner, M. F. 1984. The dawn of animal life: a biohistorical study. Cambridge University Press, Cambridge, New York, xi+244 p.

Jenkins, R. J. F. 1995. The problems and potential of using animal fossils and trace fossils in Terminal Proterozoic biostratigraphy. Precambrian Research, 73:51-69.

Jensen, S., J. G. Gehling, And M. L. Droser. 1998. Ediacara-type fossils in Cambrian sediments. Nature, 393:567-569.

McMenamin, M. A. 1998. The garden of Ediacara: discovering the first complex life. Columbia University Press, New York, xii +295 p.

Narbonne, G. M. 2005. The Ediacara biota: Neoproterozoic origin of animals and their ecosystems. Annual Review of Earth and Planetary Sciences, 33: $421-442$.

Peterson, K. J., B. Waggoner, and J. W. Hagadorn. 2003. A fungal analog for Newfoundland Ediacaran fossils? Integrative and Comparative Biology, 43:27-136.

Retallack, G. J. 1994. Were the Ediacaran Fossils Lichens. Paleobiology, 20: 523-544.

SEILACHER, A. 1992. Vendobionta and Psammocorallia-lost constructions of Precambrian evolution. Journal of the Geological Society London, 149: $607-613$.

Seilacher, A., L. A. Buatois, and M. G. Mangano. 2005. Trace fossils in the Ediacaran-Cambrian transition: behavourial diversification, ecological turnover and environmental shift. Palaeogeography, Palaeoclimatology, Palaeoecology, 227:323-356.

Seilacher, A., D. Grazhdankin, And A. Legouta. 2003. Ediacaran biota: the dawn of animal life in the shadows of giant protests. Paleontological Research, 7:43-54.

SeIlacher, A. 2007. Trace Fossil Analysis. Springer, 226 p.

SPERLING, E. A. AND J. Vinther. 2010. A placozoan affinity for Dickinsonia and the evolution of late Proterozoic metazoan feeding modes. Evolution and Development, 12:201-209.

Steiner, M. AND J. Reitner. 2001. Evidence of organic structures in Ediacaratype fossils and associated microbial mats. Geology, 29:1,119-1,122.

Tacker, R. C., A. J. Martin, P. G. Weaver, and D. R. Lawver. 2010. Trace fossils versus body fossils: Oldhamia recta revisited. Precambrian Research, 178:43-50.

Waggoner, B. M. 1995. Ediacaran Lichens - a critique. Paleobiology, 21: 393-397.

WERDING, B. AND H. SANCHEZ, 1991. Life habits and functional morphology of the sediment infaunal sponges Oceanapia oleracea and Oceanapia peltata (Porifera, Haplosclerida). Zoomorphology, 110:203-208.

Xiao, S. And M. Laflamme. 2009. On the eve of animal radiation: phylogeny, ecology and evolution of the Ediacara biota. Trends in Ecology and Evolution, 24:31-40.

Zhuravlev, A. Y. 1993. Were Ediacaran Vendobionta multi-cellulars. Neues Jahrbuch für Geologie und Paläontologie Abhandlungen, 190:299-314.

ACCEPTED 14 June 2013 